TITLE

Spain. Populism From the Far Right to the Emergence of Podemos

\title{
AUTHOR
}

Sanders, Karen B.; Berganza, Rosa; de Miguel, Roberta

\section{DATE DEPOSITED}

12 January 2017

\section{This version available at}

https://research.stmarys.ac.uk/id/eprint/1337/ 


\title{
19 Spain. Populism From the Far Right to the Emergence of Podemos
}

\author{
Karen B. Sanders, Rosa Berganza, and Roberto de Miguel
}

\section{Introduction}

There is a lack of systematic research on populism and populist political communication in Spain, consisting as it does of mainly descriptive and case study work. This state of research contrasts to the greater body of work carried out in the Latin American context. The absence of a developed corpus of theoretical and empirical research leads us to argue that caution should be exercised in assessing and classifying populism and populist communication in the Spanish context at this stage. However, the evidence that we have been able to collect from published research, survey data, media accounts, and interviews with political actors allows us to present what we hope is a useful review of the state of political populism scholarship regarding Spain.

\section{Research on Populism in Spain}

In the May 2014 European Parliament elections, Podemos (We Can), a party registered in March 2014, won five seats and 1.2 million votes. Podemos emerged from Spain's 2011 Outraged Movement. Although its activists and leaders claim that it is "neither of the left or of the right" (Carlin, 2015), most Spanish commentators consider it to be Spain's most significant left-wing populist party (see, e.g., Carlin, 2015), despite the as yet limited number of publications analyzing its rise and characteristics.

Until the appearance of Podemos, most research that centered on Spanish political populism relied on single case studies and treated the phenomenon as typical of the far right of Spanish politics in common with developments in other European countries (see Hernández-Carr, 2011, 2013). Platform for Catalonia (PxC) is considered to be the paradigm of a far-right populist party and has received most research attention to date. Few works, however, attempt to conceptualize and define populism as such in the Spanish context. Although the two major national parties have occasionally been described by the media as pursuing populist policies, Podemos is the party most widely considered to be populist by media and political commentators. The term is used exclusively in a pejorative manner in both academic and media writing, whether it is applied to left-wing or right-wing parties or to politicians. Based on limited research (Sanders, 2014) and widespread Spanish media and expert opinion, Podemos appears to conform to the definition offered by Jagers and Walgrave (2007) of an anti-elitist populist party: Its leaders make frequent references and appeals to the people, and use anti-establishment rhetoric (see Sanders, Zoragastua, \& Molina, 2015). This categorization should nonetheless be treated with caution until further systematic research can be carried out to provide rigorous analysis of the Podemos phenomenon.

Casals (2013) provides a more systematic view of the emergence of political populist actors and their styles, shared in part by a number of other researchers, as we detail below. He distinguishes three distinct waves of populism. The first wave (1989-2000) was the emergence of Italianized populism, characterized by wealthy, high-profile outsiders such as José María Ruiz Mateos (a businessman elected to the European Parliament in 1989) and Jesús Gil (president of Atlético de Madrid's football team and mayor of Marbella). In the view of Casals (2013) and others, these cases represented a kind of "berlusconization"1 of Spanish politics (Arruzza \& Mometti, 2010), understood as the adoption of a narrative that emphasized the role of managers over politicians and used anti-establishment arguments 
and appeals to, and identification with, the people (Romero, 2014). In particular, the example of Jesús Gil constitutes a paradigmatic case of complete populism (see Jagers \& Walgrave, 2007), with shades of what might be considered low-brow populism, in that it included references and appeals to the people, anti-elitism, and exclusion of outgroups. Gil's foulmouthed media appearances were considered to combine an extreme right-wing outlook with nostalgia for the pre-democratic past (Casals, 2013; Romero, 2014).

During this period, Casals (2013) described what he calls a "judicialization of politics," where politicians looked to judges and legal processes to solve political controversies and public policy issues. An example is the case of the Spanish judge Baltasar Garzón, who ran in the 1993 elections on the party list of the Spanish Socialist Workers' Party. The idea of punitive populism - understood as currying popular favor through the expansion of the state's monopoly on legitimate violence after a criminal issue becomes salient in public opinionhas also produced an abundant literature (Aizpirúa \& Fernández, 2011; Peres, 2010).

The second wave (2003-2011) "of territorial Italianization," according to Casals, began in 2003 with the appearance of Platform for Catalonia. The party's slogans ("For better control of immigrants" and "Nationals first") encapsulated an excluding style of populism, according to which references and appeals are made to the people in the context of the exclusion of outgroups. The growth of the xenophobic extreme right in Europe, although relatively insignificant in the Spanish case, was a decisive factor in the limited renewal of right-wing populism in Spain. Extreme right-wing parties abandoned their nostalgic Franco-ist discourse for the language provided by overseas xenophobic groups (see Casals, 2009).

The increased receptivity to the intolerant language of European political parties coupled with the growth of plebiscitary claims from Catalan separatists gave birth to Platform for Catalonia, a political party founded in 2002 that combined attacks on Muslim residents in Spain with pro-centralist policies. Its populism is expressed through a strategy of commonsense populism, according to which parties campaign on local issues that mainstream parties have been unable to solve. National Democracy (DN), founded in 1995, and Spain2000 , founded in 2002, are nationwide, anti-elitist, Spanish national parties. Neither of them has any significant electoral support, and they both share Platform for Catalonia's antiimmigration stance.

Catalonia has seen the emergence of a number of new populist parties (for and against independence), such as the Citizens (C's) party, founded in 2006, Catalan Solidarity for Independence (SI), and Candidature of Popular Unity (CUP) (Casals, 2013; Hernández-Carr, 2011, 2013; Rico, 2014). These parties have developed rhetorical strategies which often make strong appeals to ordinary citizens, enhancing nationalist feelings. Candidature of Popular Unity and Catalan Solidarity for Independence, both of which call for independence, might be considered as falling within the excluding populism category, together with Platform for Catalonia. Citizens appears to have adopted empty populism, which, according to Jagers and Walgrave, exists when parties base their messages on appeals and references to the people. This second wave of populism is not restricted to Catalonia. There have been a number of new political parties founded in other parts of Spain, from the personalized politics of Asturian Forum of Citizens (Uría, 2012) to the Galician nationalist, anti-elitist Galician Left Alternative (AGE) (Casais, 2013), the independence party Bildu in the Basque Country, and the Compromise party in Valencia. 
The third wave (2011-present) has been marked by economic recession, soaring unemployment rates, severe cuts to the welfare state, and a constant stream of corruption scandals affecting the whole political system from the monarchy, mainstream parties, and members of parliament to regional deputies and local mayors. Systemic instability has also been exacerbated by Catalan demands for independence, bringing into question the viability of Spain's 1978 constitutional settlement establishing a decentralized, unitary state composed of 17 autonomous communities. This is the context for the appearance of new populist actors whose anti-elitist or anti-politics voices associate the ruling "political class" with defending the interests of the financial system at the expense of the people (Stobart, 2014).

Spain's deepening recession between 2008 and 2013 provided the context for growing popular demands for reforms to create a more participatory, horizontal democracy instead of the prevailing model of representative democracy. Movements such as the 15-M Movement and the 25-S initiative ("Occupy the congress") gave birth to the slogan "The people against the parliament." According to Durgan and Sans (2011), both mass movements could be understood as being born out of the public's perception that mainstream politics was broken or hollowed out, no longer representing the citizens' interests. Although the recession and the dismantling of the welfare state undoubtedly contributed to the feeling of disenchantment with official politics, the authors maintain that rather than being anti-austerity movements, as was the case in Greece and Portugal, Spain's 15-M and 25-S movements were seeking a new politics to replace the old, broken model.

It is in this context that we can place the rise of Podemos, the new radical "citizens' movement" party. Founded in January 2014 and having a crowdfunded budget of just $€ 150,000$, Podemos obtained, as we saw earlier, 1.2 million votes and five seats in the May 2014 European Parliament elections. Eight months later, even more surprisingly, Podemos was leading the polls ahead of the two major parties, the People's Party (PP) and the Spanish Socialist Workers' Party (PSOE), which had monopolized Spanish politics for over 30 years (Barriere, Durgan, \& Robson, 2015).

Until the emergence of Podemos in 2014, populist parties were largely focused on garnering regional or peripheral nationalist support (the case of the Catalan and Galician parties), and to date, they have received relatively low-level electoral support. Platform for Catalonia, for example, received just over two percent of the Catalan vote in the 2010 regional elections and, in the 2011 national elections, it received a total of 59,363 votes, falling below the number required to obtain parliamentary representation. The party had more success in the 2011 local elections in Catalan towns with large immigrant populations, where voters elected 67 town councilors compared to 17 in the previous 2007 local elections.

Citizens (the nationwide successor party to the Catalan Citizens party), on the other hand, achieved a significant breakthrough in electoral support in the 2014 European Parliament elections, gaining around three percent of the vote and two seats in the Parliament, with the two ministers becoming members of the Alliance of Liberals and Democrats for Europe group. This breakthrough was consolidated in the 2015 regional and municipal elections, in which the party gained over six percent of the national vote and was labeled by some media commentators as "the Podemos of the right" (Kassam, 2015).

We have already noted the astonishing results chalked up by Podemos in the 2014 European Parliament elections. The governing conservative Popular Party lost 2.6 million votes and 
eight members of the European Parliament (MEPs); the socialist main opposition party lost 2.5 million votes and nine MEPs. By October 2014, 14\% of Spaniards said that they would vote for Podemos in the next general elections, and by January 2015, this figure had risen to almost 24\%, pushing Podemos into second place after the People's Party, for whom just over 27\% of Spaniards declared their intention to vote, and leaving the Spanish Socialist Workers' Party in third position, with around $22 \%$ of the intended vote (Centro de Investigaciones Sociológicas, 2015). However, when asked "Supposing general elections were held tomorrow, what party would you vote for?" Podemos emerged as the victor, with $19 \%$ of Spaniards declaring that they would vote for the party, followed by the Popular Party (almost 13\%) and the Spanish Socialist Workers' Party (just over 12\%) (Centro de Investigaciones Sociológicas, 2015). Many commentators declared that these survey figures marked the end of two-party politics in Spain (Cué, 2015).

To conclude this survey of political populism scholarship and knowledge in Spain, it should be noted that more systematic and comparative research of political populism has been carried out in the Latin American context (see Mansilla, 2011). Sociologists, historians, and political scientists have provided the bulk of research, seeking to pin down what they consider to be a slippery concept (Weyland, 2001) or to explore the political economy or ideological rationales that give rise to populism (Miralles, 2011). Most work has been directed toward providing political and socio-economic explanations for the development of political populism and to the analysis of populist political actors, as we shall now see (see Rivas \& Araque, 2004).

\section{Populist Actors as Communicators}

At the time of writing, there is little systematic research about populist actors' styles, strategies, and language. Most media and academic analysis is descriptive and impressionistic, pointing to the declarations and actions of the leaders of Podemos as evidence for a well-crafted and professional communication strategy that makes clever use of a combination of mainstream and social media (Carlin, 2015; Sanders, 2014).

Podemos's leader, Iglesias, and his colleagues center their communication efforts on four main themes (Sanders, 2014). First, the corruption of mainstream Spanish politics: They repeatedly denounce the "revolving doors" between governments and the advisory and executive boards of corporations (Errejón, 2011; Iglesias, 2014) and emphasize the all-tooreal corruption scandals of the two major political parties that have dominated headlines in the recession years. Second, by constant use of the term casta (caste, ruling class), they position themselves as being "the people," in contrast to the self-interested political and business elites who govern for themselves rather than for the country. Third, they argue for new participatory politics that will replace "the myth of representation," coinciding with the 15-M Movement's motto, No nos representan ("They do not represent us"). Finally, the leaders of Podemos argue that their politics leaves behind the false dichotomies of left and right for "commonsense" politics. Ínigo Errejón (2014), political science researcher and the chief campaign strategist of Podemos, summed up the political communication strategies of his party in the following terms:

The Podemos campaign assumed that in politics the signifiers themselves live within struggles to give them one direction or another, and that the choice of one depends on the positions of their authors. This constructivist view of political discourse has allowed a transverse appeal to a disgruntled social majority which is beyond the leftright divide. It is these kinds of divisions that the regime established, ensuring 
its stability. But by offering the dichotomies "democracy/oligarchy", "citizenship/caste" or even "new/old", Podemos established new borders to isolate elites and propose a new identification in order to better position ourselves in relation to them. (Errejón, 2014, n.p.)

A qualitative study of Podemos's 2014 European electoral communication (see Sanders et al., 2015) found that the party's communication content and aesthetics (presentational style) was anchored in appeals to, and identification with, the people through words and images together with an anti-elite narrative. In their campaign video, for example, images of Iglesias as an ordinary citizen putting clothes into the washing machine, filling out his tax return, and catching a bus were contrasted with images and words of the two mainstream rival candidates in their official cars, remote from the cares of normal life (see Podemos campaign video 2014). Iglesias's casual dress style and appearance, usually tie-less and pony-tailed, contrasted with the more staid, conventional look of his opponents. The party's election events took place in ordinary places such as state schools and street pavements, unlike the more upmarket locations for the conservatives' and socialists' campaigns.

A number of authors (Aira, 2010; Laguna, 2013) have examined the effects of political marketing and the professionalization of political communication on democratic politics in Spain. These descriptive studies adopt a normative critique of political communication strategies, pointing to what some consider to be their "corrupting" impact on the public sphere since market demands, "fostered by the media and measured by opinion polls, become the basis of proposals and speeches" (Laguna, 2013, p. 3). This marketization of politics is considered to contain a populist and even demagogic dynamic that is deleterious for democratic principles and values. No comparative research, however, examines systematic differences and similarities in the rhetorical styles and language of populist and mainstream parties and politicians. Some authors have touched on what might be considered tangentially related themes. Pena and Ortiz (2011), for example, explore the use of political slogans in Spanish election campaigns, describing those which suggest that power and virtue reside with "the people" as populist. Aira (2010) points to the growing dominance of specific communication formats, driven by professional spin doctors, who seek to ensure that politicians communicate with their audiences in ways that suit the televisual language of spectacle.

In general, the main focus for Spanish-language scholars or Hispanists publishing in English has been on Latin American populist actors such as Hugo Chávez (President of Venezuela from 1999 until his death in 2013), the Revolutionary Institutional Party (PRI) in Mexico, and Albert Fujimori (President of Peru from 1990 to 2000). This work highlights (a) a growing tendency toward personalization of politics, (b) the use of emotional appeals coupled with anti-establishment messages, (c) the exaltation of party leaders in the context of citizens' depoliticization and rejection of traditional politics, (d) the articulation of Manichean discourses with a particular emphasis on the dichotomies "us/me versus them" or "the people versus the political elite." These features are also clearly present in the Spanish context.

\section{The Media and Populism}

There appear to be no studies specifically dealing with the media and populism or populist political communication. Cebrián and Berrocal (2013) have examined the growth of infotainment media and media formats that privilege the visual and the frivolous and, in their view, "decontextualize" politics, displacing "traditional political argumentation with banal or superficial aspects" (p. 273). Their analysis, however, made no specific mention of populist 
political communication. Aznar's (2005, p. 2) discussion of telebasura (literally, "rubbish TV," although "tabloid TV" best expresses the term's meaning) lamented the state of Spanish television, which he considered to be more interested in political personalities than political ideas. He suggested that television programming should not be simply populist but should respond to the professional ethics of responsible communication in a democracy.

Since the 1990s, the Spanish press has experienced a process of adaptation to the dramatic changes in the media marketplace brought about by the financial crisis. Among those innovations, perhaps the most noteworthy has been the drive toward the popularization of content to ensure the widest possible audience (Beam, 2003). Political news, both in the mainstream newspapers and in the tabloid free dailies, is increasingly founded on emotional appeals to ensure the widest possible audience, with the result that the imperatives of show business at times outweigh considerations of quality and accuracy (Berganza Conde \& de Miguel Pascual, 2010; Labio, 2008). However, Spain does not have an equivalent to the British or German tabloid populist press and its mass audience. Newspaper readership is historically low compared to the rest of Europe.

The 15-M Movement as well as the emergence of Podemos have produced what Palao (2015) has described as a hybrid form of political communication that combines the use of mainstream broadcasting formats and of social media. Podemos's leader, Iglesias, gained visibility first as a television commentator on community cable channels in programs such as La Tuerka and Fort Apache, and then as a popular talk-show debater. As Errejón explained, "the use of the media leadership of Pablo Iglesias was a condition sine qua non of the crystallization of political hope" (2014, p. 1). Mimicking the 5 Star Movement in Italy, Podemos's strategy was also founded on the promotion of social media to open up the party model and show its opposition to the representative party system (Rodríguez-Aguilera de Prat, 2015). During the 2014 European election campaign, Podemos effectively engaged the public through the use of social media such as Twitter and Facebook. Its use of social media made clear the generational gulf between the younger leaders of Podemos and those of the mainstream parties, who were men and women at least one generation older. Iglesias opened a Twitter account in 2010 and habitually used it to communicate with his followers. By the time of the European elections he had around 500,000 followers (Bollero, 2014). The People's Party candidate, Miguel Arias Canete, only created his Twitter account shortly before the European elections, and he exclusively used it to send messages to his almost 20,000 followers, having no interaction with them whatsoever (see Rodríguez, 2014).

On Facebook and YouTube, Podemos also outdid its mainstream rivals in terms of presence and content. By August 2014, the party had around 700,000 Facebook likes, compared to fewer than 200,000 for the People's Party and Socialist Workers' Party. Podemos also had tripled the number of subscribers to its YouTube videos, registering over 30,000, compared to fewer than 10,000 subscribers to the Spanish Socialist Workers' Party's videos and fewer than 5,000 to those of the People's Party (see Bollero, 2014). Podemos's digital natives used social media as a means to generate a conversation with sections of the Spanish population who had not previously voted.

\section{Citizens and Populism}

We have not identified any studies that explore the effects of populist political communication on citizens in Spain. Several studies of Latin American populism refer to the specific proclivity of what they call the "popular" classes to be manipulated by populist actors but without providing robust empirical evidence for these claims. 
Evidence can be found regarding who votes for populist parties in the regular opinion surveys carried out by Spain's national survey agency, the Centro de Investigación Social, and in one small-sample case study of prospective voters for the Platform for Catalonia in the 2010 regional elections (Hernández-Carr, 2013). A post-electoral study of the 2014 European Parliament elections (Institut Balear de Estudios Sociales, 2014) showed that Podemos picked up a large number of votes from the two main left-wing parties, with the Spanish Socialist Workers' Party losing most voters, followed by the United Left. It also won some votes from the ruling conservative People's Party. Many votes were gained from those who had abstained in the previous elections or those who were voting for the first time. The young demographic (18-21) of the latter group was reflected in the fact that $29 \%$ of Podemos's voters were aged between 18 and 35. No significant gender differences were found, and voters were characterized by a wide spread of ideological affiliations, with two percent declaring themselves to be right wing, nine percent belonging to the center, and $12 \%$ saying that they considered themselves to be left wing.

Based on an Internet-based survey and a small number of interviews, the Hernández-Carr study (2013) showed that traditional party identifications have weakened considerably, especially among young people. He suggests that this weakening could mean that voters, and particularly younger voters, are more likely to vote for populist parties. To date, however, radical right parties have achieved no widespread electoral support in Spain. As Alonso and Rovira Kaltwasser (2014, p. 24) point out, "there are only two countries in which PRR [populist radical-right] parties have never obtained more than one per cent of the vote in any national election: Portugal and Spain." This situation is in contrast to many European countries, where populist radical-right parties have tended to be the mouthpiece for the politics of disillusion and protest (see Mudde, 2007).

Alonso and Rovira Kaltwasser (2014) argue, however, that the lack of support for populist radical-right parties in Spain cannot necessarily be attributed to an absence of demand-side factors supporting their emergence but is more readily explained by supply-side factors inhibiting their growth. They point to three key factors: Spain's electoral system, which tends to disfavor electoral representation of small nationwide parties; the electoral strategy of the mainstream right that occupies some of the ideological ground of the far right; and, finally, the character of the ideological cleavages marking Spanish politics. The authors consider this last factor to be particularly significant in reducing the possibility of the emergence of populist radical-right parties. Since 1979, Spanish electoral competition has been dominated by the socioeconomic, left-right ideological cleavage and the centerperiphery debate about state nationalism and ethno-nationalism, leaving populist radical- right parties with little ideological space to occupy. Thus, the authors suggest that Spanish supply-side factors make it improbable that a populist radical-right party could achieve widespread electoral support. At the same time, they note that left-wing populist politics - which uses a narrative of the people versus the elite - can more effectively negotiate the peculiarities of the Spanish electoral landscape and win more support from voters.

\section{Summary and Recent Developments}

The emergence of Podemos as well as other political groups together with the popular disillusionment with, and distrust of, mainstream politicians and political parties have placed the phenomenon of political populism firmly on the Spanish political and public agenda. A number of articles and commentators decrying the growth of populism — and especially the ideological program and international and particularly Venezuelan connections of Podemos 
and its leaders - have appeared in the Spanish media. At the time of writing, however, there has been no rigorous, systematic study in the Spanish context that defines populism or provides a thorough empirical analysis of the strategies and tactics of populist actors. Nor is there research examining either the role of the media in populist political communication or the latter's effects on citizens. Much of the research related to political populism in Spain is descriptive and atheoretical in character. Researchers on political populism in Spain have their work cut out for them to keep pace with the country's fast-moving political reality.

\section{Note}

1. This word is a reference to the Italian politician, Silvio Berlusconi, and his style of politics.

\section{References}

Aira, T. (2010). Analisi, 40, 15-27.

Aizpirúa, E., \& Fernández, E. (2011). Información, .antídoto frente al populismo punitivo. Revista Espanola de Investigación Criminológica, 3(9), 1-29.

Alonso, S., \& Rovira Kaltwasser, C. (2014). Spain: No country for the populist right? South European Society and Politics, 20(1), 21-45.

Arruzza, C., \& Mometti, F. (2010). Amenazas de derechas: el berlusconismo y la transición autoritaria. Viento sur: Por una izquierda alternativa, 111, 42-51.

Aznar, H. (2005). Democracia y programación televisiva. Telebasura y ética de la comunicación. Telos, 63. Retrieved from http://telos.fundaciontelefonica.com/telos/articuloperspectiva.asp@idarticulo=2\&rev= 63.htm.

Barriere, M., Durgan, A., \& Robson, S. (2015). The challenge of Podemos. International Socialism: A Quarterly Journal of Socialist Theory, 145. Retrieved from http://www.isj.org.uk/index.php4?id=1028\&issue $=145$.

Beam, R. A. (2003). Content differences between daily newspapers with strong and weak market orientations. Journalism \& Mass Communication Quarterly, 80(2), 368-390.

Berganza-Conde, M. R., \& de Miguel Pascual, R. (2010, October). Free dailies and quality standards: A comparative-exploratory analysis of journalistic excellence among five Spanish daily newspapers. Paper presented at the 3rd European Communication Conference, Hamburg, Germany. Retrieved from http://www.researchgate.net/publication/271586461.

Bollero, D. (2014, August 16). Podemos se consolida como la primera fuerza política en redes sociales. Público. Retrieved from http://www.publico.es/.

Carlin, J. (2015, January 21). Los caballeros de la Mesa Redonda. El País. Retrieved from http://politica.elpais.com/.

Casais, M. B. (2013). Alternativa Galega de Esquerdas: un actor diferencial en las elecciones gallegas de 2012. Revista de Investigaciones Políticas y Sociológicas, 12(3), 143-161.

Casals, X. (2009). La renovación de la ultraderecha espanola: una historia generacional (1966-2008). Historia y Política, 22, 233-258.

Casals, X. (2013). El pueblo contra el Parlamento. El nuevo populismo en Espana, 1989 2013. Madrid, Spain: Pasado y Presente.

Cebrián, E., \& Berrocal, S. (2013). La irrupción del "infoentretenimiento" en la comunicación política espanola. Una propuesta para la sistematización de sus formatos televisos. In K. Sanders, M. J. Canel, A. Capdevila, \& M. Gurrionero, (Eds.), Estudios de Comunicación Política. Libro del Ano 2012 (pp. 260-275). Madrid, Spain: Tecnos.

Centro de Investigaciones Sociológicas. (2015). Barómetro de enero 2015 (Study No. 3050). Retrieved from http://datos.cis.es/pdf/Es3050mar_A.pdf. 
Cué, C. (2015). Podemos desbanca al PSOE como segunda fuerza política. El País. 4 February. Retrieved from http://politica.elpais.com/.

Durgan, A., \& Sans, J. (2011). "No one represents us": The 15 May Movement in the Spanish state. International Socialism, 132(Autumn). Retrieved from http://www.isj.org.uk/.

Errejón, I. (2011). Política, conflicto y populismo (I). La construcción discursiva de identidades populares. Viento sur: Por una izquierda alternativa, 114, 75-84.

Errejón, I. (2014). Spain's Podemos: An inside view of a radical left sensation. Revolting Europe [Blog]. 15 July. Retrieved from http://revolting-europe.com/.

Hernández-Carr, A. (2011). .La hora del populismo? Elementos para comprender el "éxito" electoral de Plataforma per Catalunya. Revista de Estudios Políticos, 153, 47-74.

Hernández-Carr, A. (2013). El salto a la nueva extrema derecha: una aproximación a los votantes de Plataforma per Catalunya. Politica y Sociedad, 50(2), 601-627.

Iglesias, P. (2014). Disputar la democracia. Barcelona, Spain: Akal.

Institut Balear de Estudios Sociales. (2014). Postelectoral Europeas 2014.1 June. Retrieved from http://www.ibesinvestigacion.com/postelectoral-europeas-2014/.

Jagers, J., \& Walgrave, S. (2007). Populism as political communication style: An empirical study of political parties' discourse in Belgium. European Journal of Political Research, 46(3), 319-345.

Kassam, A. (2015). Ciudadanos, the "Podemos of the right", emerges as political force in Spain. The Guardian. 15 March. Retrieved from http://www.theguardian.com/.

Labio, A. (2008) Periodismo de entretenimiento: la trivialización de la prensa de referencia. Estudios sobre el Mensaje Periodístico. 14, 435-447.

Laguna, A. (2013). La profesionalización comunicativa: partidos políticos o empresas de comunicación. Ámbitos. Revista internacional de comunicación, 22(1), 11-20.

Mansilla, H. C. F. (2011). Aproximaciones teóricas a la comprensión del populismo contemporáneo en América Latina. Revista de Estudios Políticos, 152, 11-47.

Miralles, X. A. (2011). "El pueblo y sus opresores": populismo y nacionalismo en la cultura política del radicalismo democrático, 1844-1848. Historia y Política, 25, 65-91.

Mudde, C. (2007). Populist radical right parties in Europe. Cambridge, UK: Cambridge University Press.

Palao, J. A. (2015). La enunciación compleja: hermenéutica, semiótica y política en el siglo XXI. El caso de Podemos. Castelló de la Plana. Retrieved from http://www.comunicambio2015.uji.es/language/es/.

Pena, P., \& Ortiz, M. A. (2011). El eslogan político espanol en la campana de elecciones generales de 2008. Estudios sobre el Mensaje Periodístico, 17(2), 549-568.

Peres, L. (2010). Prensa, política criminal y opinión pública: el populismo punitive en Espana. Spain: Universitat Autonoma de Barcelona. Podemos campaign video 2014. (2014, May 18) [Video file]. Retrieved from https://www.youtube.com/watch?v=NuUvtVhe0gE.

Rico, G. (2014). El populisme: d'estigma a categoria analítica. Ambits de Política i Societat: Revista del Collegi de Politolegs i Sociolegs de Catalunya. 9 December. Retrieved from http://ambitscolpis.com/.

Rivas, J. A., \& Araque, J. (2004). Aventuras y desventuras del populismo latinoamericano. Revista de Estudios Políticos, 124, 229-244.

Rodríguez, G. (2014). Cómo han (mal)utilizado Twitter los candidatos. El Huffington Post. 25 May. Retrieved from http://www.huffingtonpost.es/.

Rodríguez-Aguilera de Prat, C. (2015). Semejanzas y diferencias entre el Movimento 5 Stelle. y Podemos. Societa Mutamento Politica. 6(11), 51-74. 
Romero, C. R. (2014). Populismo durante la era Aznar: el GIL en Ceuta. In Actas del IV Congreso de Historia de Nuestro Tiempo (pp. 315-320). Logrono, Spain: Universidad de La Rioja.

Sanders, K. (2014, October 10). The emergence of Spain's Podemos (We Can) Party:

Challenges for political communication practice and study. Keynote presentation at II International Conference on Political Participation and Web 2.0, University of Beira Interior, Covilha, Portugal.

Sanders, K., Zoragastua, J., \& Molina, M. J. (2015, July). Immigration and the framing of the other in populist politics. Why "Spain is different." Paper presented at the International Association for Media and Communication Research conference, Montreal, Canada.

Stobart, L. (2014, November 5). Understanding Podemos (1/3): 15-M \& counter-politics. Left Flank [Blog]. Retrieved from http://tinyurl.com/pcfc45t.

Uría, C. (2012). El Foro Asturias, originalidad asturiana o algo más? Página Abierta, p. 220. Retrieved from http://www.pensamientocritico.org/cheuri0612.htm.

Weyland, K. (2001). Clarifying a contested concept: Populism in the study of Latin American politics. Comparative Politics, 34(1), 1-22 